\title{
Element Modeling of Masonry Wall With Opening Under Lateral Force
}

\author{
Danna Darmayadi ${ }^{1 *}$, Muhamad Rusli A. ${ }^{2}$ \\ 1, 2 Department of Civil Engineering, Sultan Agung Islamic University, Semarang, Central Java, \\ Indonesia \\ *Corresponding author: darmayadi@yahoo.com
}

(Received: September $2^{\text {nd }}, 2018$; Revised: October $10^{\text {th }} 2018$; Accepted: October $20^{\text {th }} 2018$ )

\begin{abstract}
Three-dimensional Finite Element Model for Masonry Wall with openings under lateral force using ABAQUS software. Finite element model verification with an experiment masonry wall in the laboratory without openings. The load-displacement relationship of finite element model is well agreed with experimental results. Parametric studies conducted on masonry wall with openings to investigate the influence of an area of openings. This research aimed to investigate the behavior of Masonry Walls with openings under lateral force. The result showed that the increase of the area of openings decreases stiffness and strength of masonry. It is also well observed from the result that lateral resistance of masonry will decrease for each area of the opening wall.
\end{abstract}

Keywords: Finite element; ABAQUS Software; Masonry wall with an opening; Lateral Force.

\section{Introduction}

Indonesia is located in the earthquake zone, has caused many buildings to suffer damage because of the earthquake. When a building receives an earthquake, the biggest damage is nonengineered structures. A masonry wall is nonengineered structures which in the construction is often not calculated. In a masonry wall, there is an opening which has a reduced area of the wall, due to the placement of doors or windows. Reduced the area of the wall will affect the behavior of the masonry wall.

Research on masonry that receives the lateral force has been done, Hakas [1] researched the prediction lateral in a plane through changes natural frequency and the damping of the structure of Masonry Wall 1/2 brick with mortar 1 Pc: 4 Lime: 10 Sand. While Satyarno [2] researched Masonry strength due to static and cyclic load. The masonry walls with openings have been Research by Archana [3] researched the effect of openings and the ratio of openings to masonry walls on concrete frames. Whereas Bashar [4] researched the behavior of structures with opening walls that received Compressive Loading. Putra [5] researched the effect of the location of openings on the performance of confined masonry walls with cyclic loads.

The Finite Element Method has been widely used by researchers to analysis Masonry walls, the researchers using the Finite Element Method in analyzing Masonry walls such as Stavridis [6] used Finite Element to determine the behavior of concrete masonry walls, Mohyeddin [7] modeled by using the ANSYS program, Alchaar [8] and D'ayala [9] used the ALGOR program to model Finite Element, Stavridis [10] modeled concrete masonry walls provided with seismic loads. 
ABAQUS software has been widely used in the model of finite Element modeling on the Masonry wall. Chen [11] simulate damage to Masonry walls using the Abaqus program. Maeillyta [12] model the Masonry walls with ABAQUS openings, Moghadam [13] used the ABAQUS program to model the Masonry walls.

The aims of this research are to comprehensively investigate the behavior of Masonry Walls with an opening under lateral force (1) 3-dimensional modeling using ABAQUS Software. (2) Find the load and displacement Curve, (3) Find the damage of masonry wall with variations of openings.

\section{Modeling of Finite Element}

Masonry walls are modeled using ABAQUS software, geometric details, loads and materials applied to Abaqus software described below:

\subsection{Geometric and load modeling}

Model created with scale 1:1 with dimensions of $3 \times 3 \times 0.15 \mathrm{~m}$ are placed on a reinforced concrete sloof. Finite Element modeling adapted using the experiments of Hakas (2017) as verification of finite element model.

A masonry wall with mortar was modeled with a homogeneous material. Used constrain tie to connect between the Masonry walls and concrete. Reinforcement is modeled using 2 nodes, linear truss element and embedded in concrete material performed, measure displacement in line with the lateral load and use un-restrain in some direction of load and restrain in another direction. Fig. 1 shows the meshing in modeling Finite Element and Fig. 2 shows apply lateral force in a solid Masonry wall

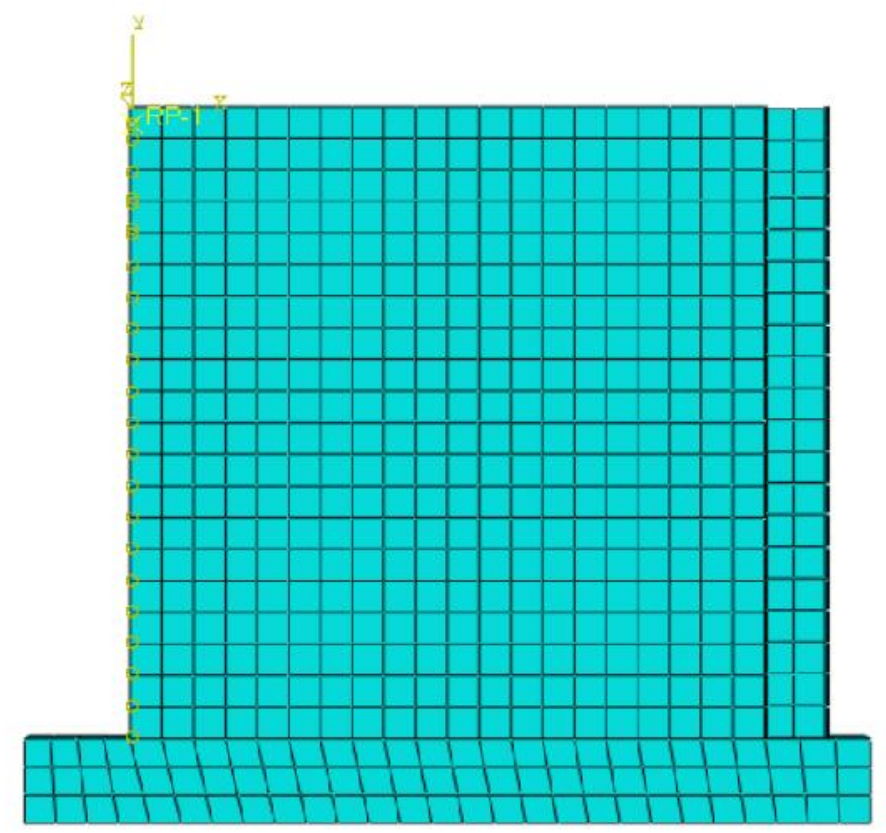

Fig 1. Meshing Finite element Model of Solid Masonry wall 


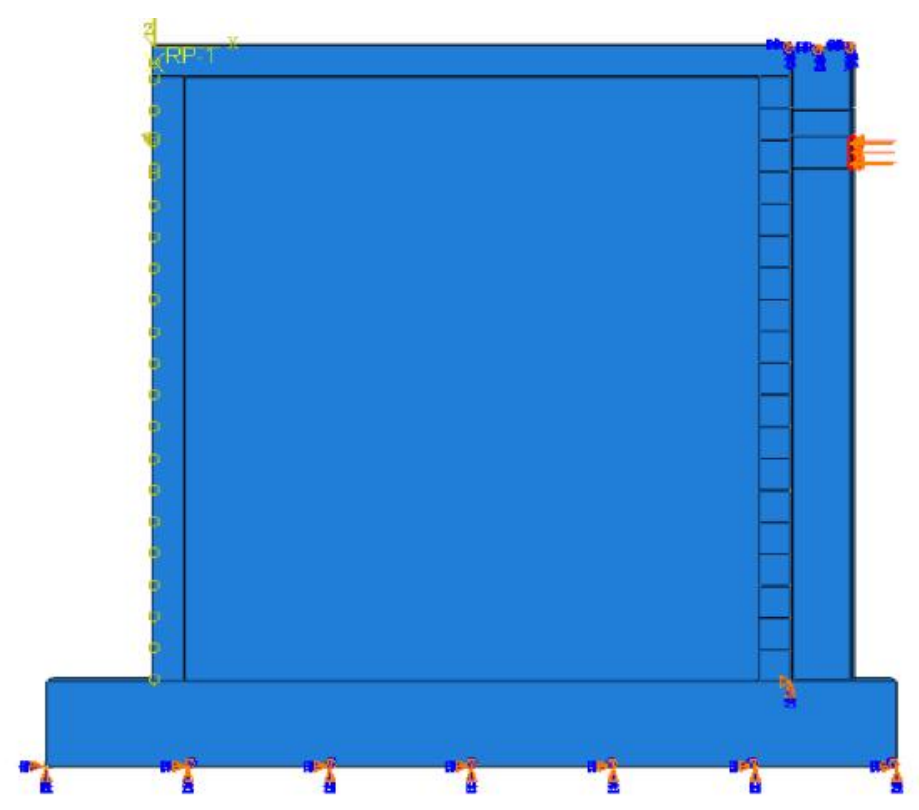

Fig 2. Apply lateral force in a solid Masonry wall

\subsection{The material in Abaqus Model}

Data Material of concrete and reinforcing for the modeling of finite element used data from the experiments of Hakas (2017). Material data used can be explained as follows:

\subsubsection{Concrete}

Concrete used for beams and columns have compressive strength 15.6142 MPa. Stress-strain curve for concrete compressive strength calculated based on BS EN 1992-1-1 [14] and for tensile strength based on Wang [15] (See Fig. 3 and fig. 4). Other parameters used in concrete are Density $=2400 \mathrm{~kg} / \mathrm{m} 3$, modulus of Elasticity $=18569.46 \mathrm{MPa}$, Poison Ratio 0.2, Dilation Angle $=300$, Flow potential eccentricity $=0.1$, Ratio of initial equi-biaxial compressive yield stress to initial uni-axial compressive yield stress $=1.16$, Ratio of second stress invariant $=0.667$, Viscosity parameter $=0.005$.

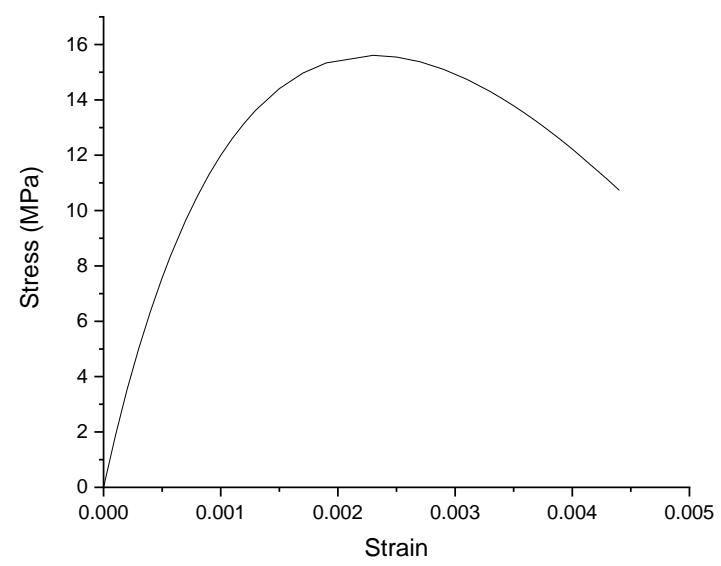

Fig 3. Constitutive model in ABAQUS for the Compressive strength of Concrete -BS EN 1992-1-1 [14] 


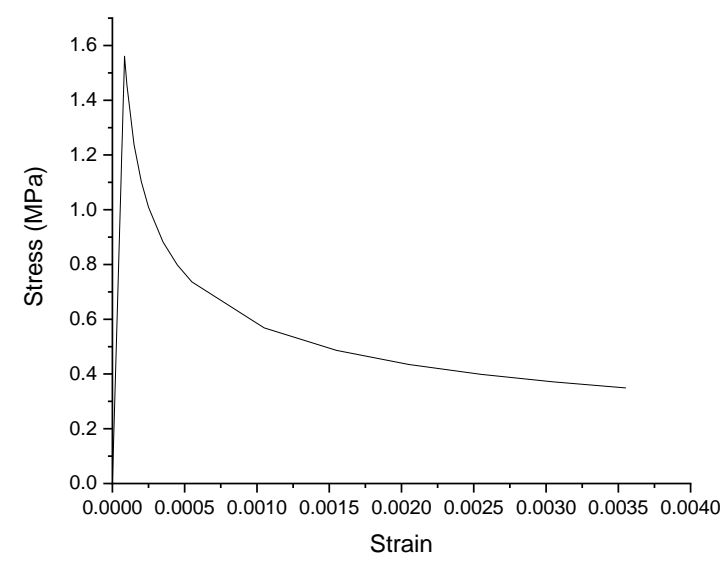

Fig 4. Constitutive model in ABAQUS for the tensile strength of concrete - Wang [15]

\subsubsection{Steel for reinforcement}

Steel for reinforcement used grade U39 for the diameter of 8 and a diameter of 6. Fig. 5 and Fig. 6 shows the results of the tensile test for the diameter of 8 and 6. Other parameters used in steel reinforcement materials are: Density $=7850 \mathrm{~kg} / \mathrm{m} 3$, Modulus of Elasticity $=197724.7 \mathrm{MPa}$, Poisson's ratio $=0.3$

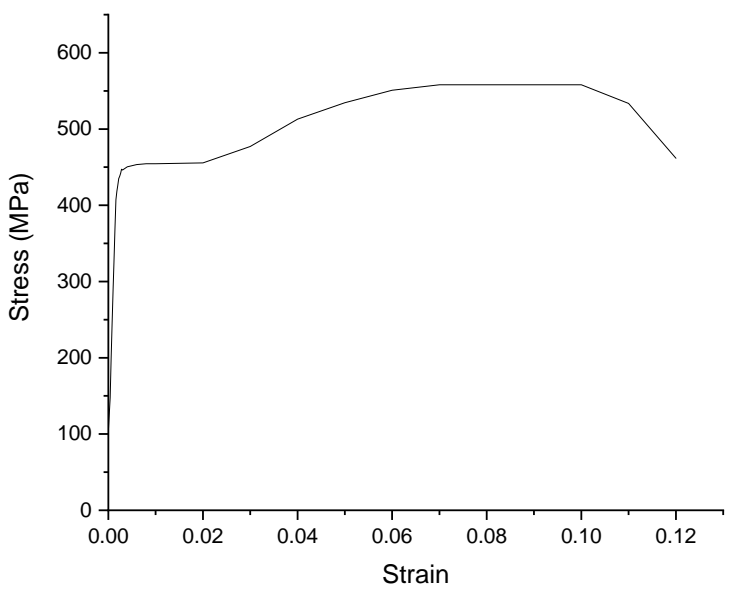

Fig. 5. Stress-strain curve diameter $8 \mathrm{~mm}$ (Hakas 2017) 


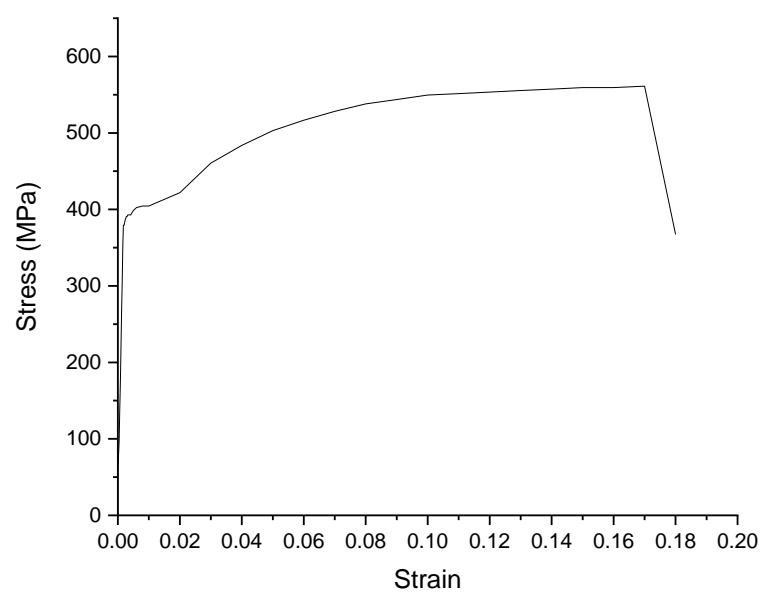

Fig. 6. Stress-strain curve diameter 6 mm (Hakas 2017)

\subsubsection{Masonry}

The compressive strength of the masonry walls was calculated using the Equations of T. Paulay [16]. The formula use data of the size of a brick, the distance between the thicknesses of the mortar, the compressive strength of brick, the compressive strength of mortar. Equations used for calculation are:

$$
f_{I m}^{\prime}=\emptyset\left\lfloor x f_{p}^{\prime}+(1-x) f_{y}^{\prime}\right\rfloor
$$

and

$$
f_{p}^{\prime}=f_{y}=\frac{f_{c}^{\prime}\left(f_{t}^{\prime}+\alpha f_{j}^{\prime}\right)}{U_{u}\left(f_{t}^{\prime}+\alpha f_{c}^{\prime}\right)}
$$

Where:

$f^{\prime} m=$ compressive strength of Masonry wall (MPa)

Table 1. The compressive strength of masonry

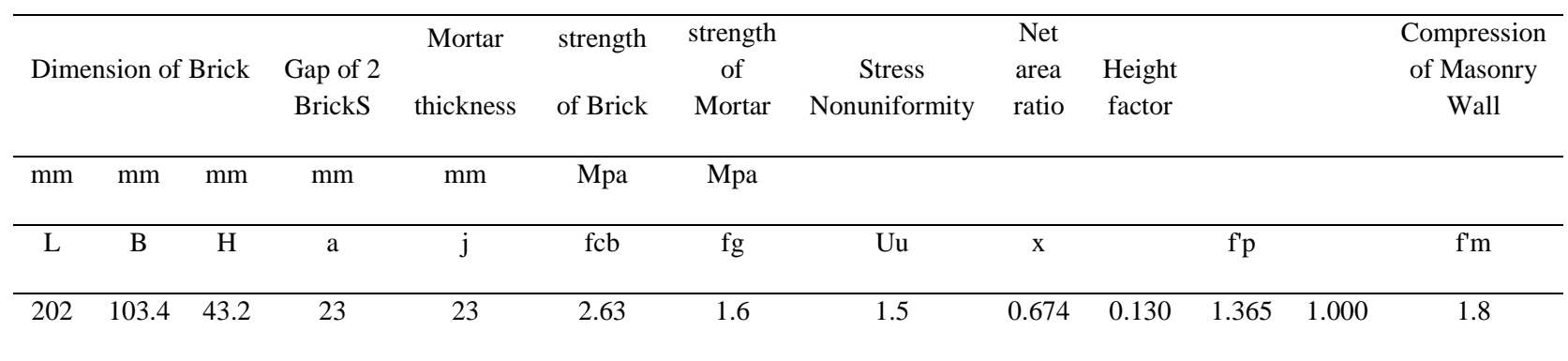

Stress-strain curve for compressive strength of masonry calculated based on Kaushik [17] and for the tensile strength of masonry based on Chen [18]. (See Fig. 7 and fig. 8) 


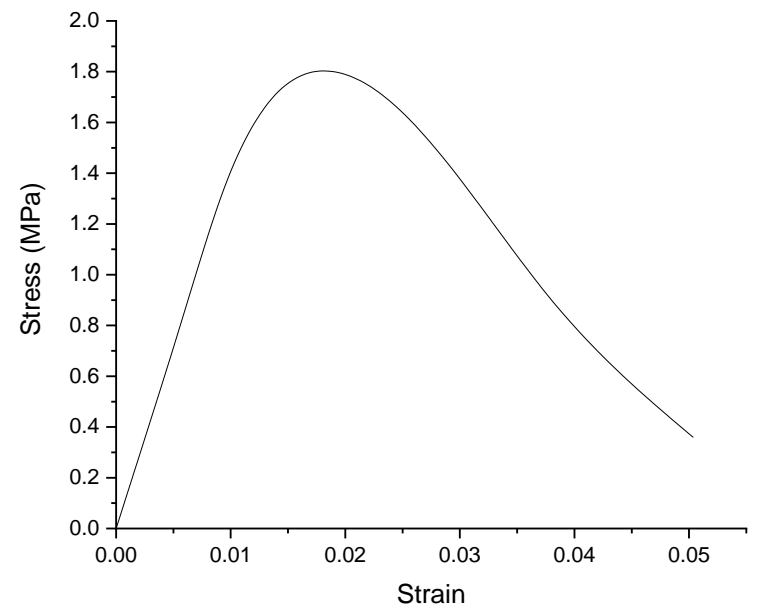

Fig 7. Constitutive model in ABAQUS for the Compressive strength of masonry - Kaushik [17]

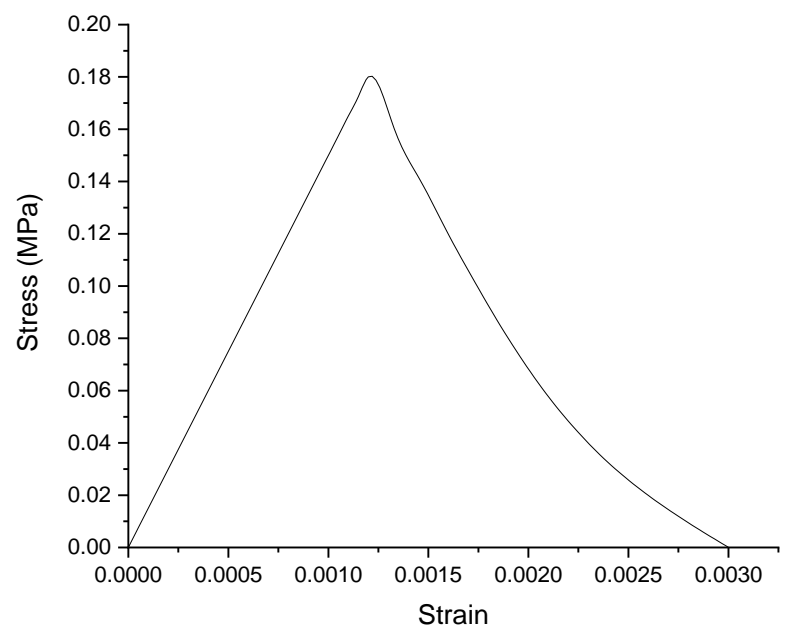

Fig 8. Constitutive model in ABAQUS for the tensile strength of masonry - Chen [18]

\section{Verification of Finite Element Models}

Verification of Finite Element Models using experiment Hakas [1]. Model experiment using scale 1:1 with dimensions of $3 \times 3 \times 0.15 \mathrm{~m}$ placed on reinforced concrete slabs. The masonry walls contain concrete frames with beam and column sizes of $0.15 \times 0.15 \mathrm{~m}$ and there are plastering on both sides with a mortar of 1 PC: 4 Lime: 10 sand. With $2 \mathrm{~cm}$ thick. The details of the reinforcement can be seen in Fig. 9. The experiment used 3 LVDT Place in Left Model in the horizontal direction to record lateral displacement and micro vibration testing using the accelerometer to record the frequency of the model masonry wall. See fig. 10 for Experiment set up of Hakas [1] 


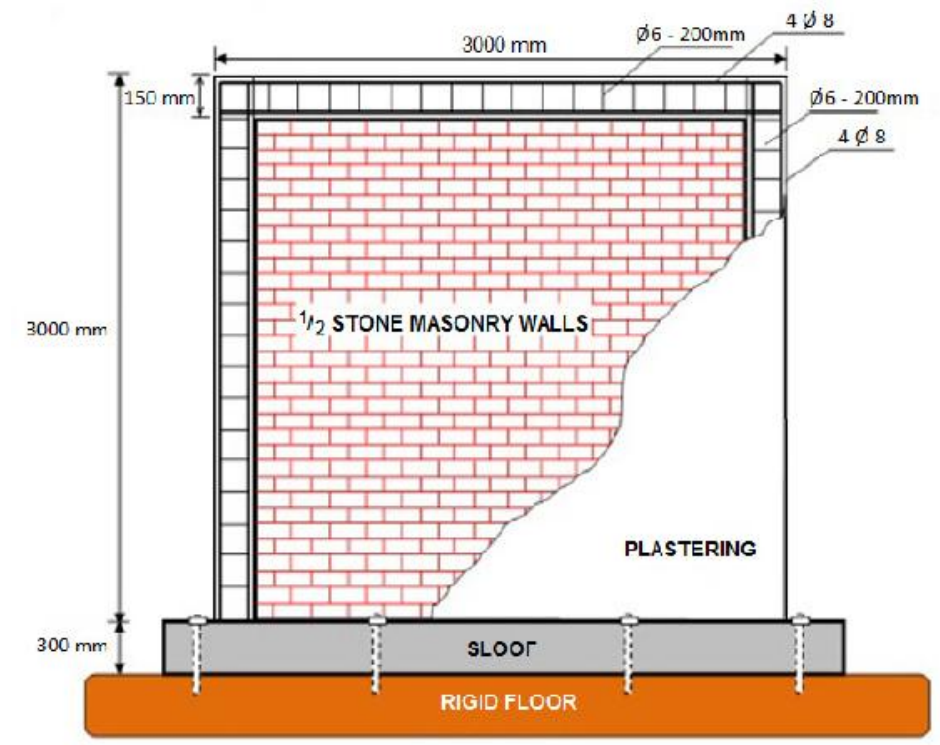

Fig 9. A specimen of the wall - Hakas [1]

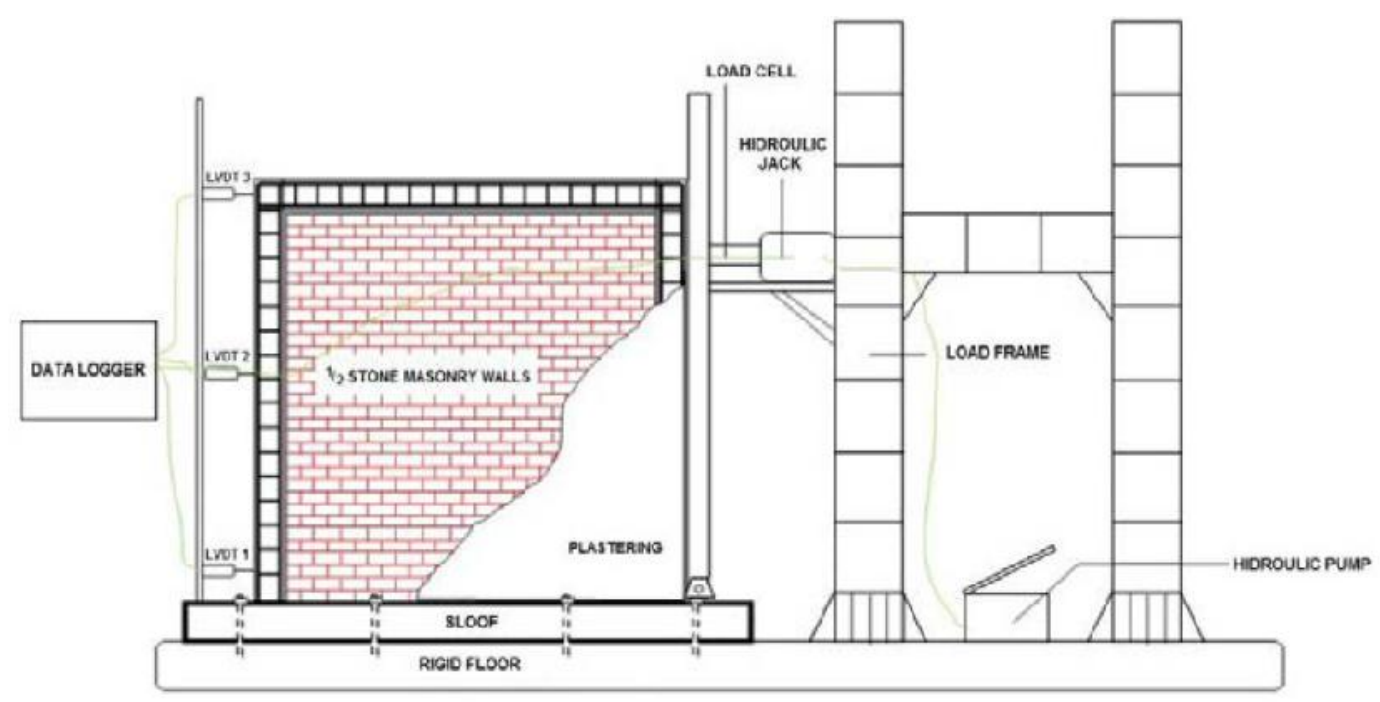

Fig 10. Experiment set up of Masonry Wall - Hakas [1]

Models of Masonry was given lateral load with the stages of loading which can be seen in table 2.

Table 2. Lateral Force apply in Masonry wall - Hakas [1]

\begin{tabular}{ccc}
\hline \multirow{2}{*}{ Load } & \multicolumn{2}{c}{ Load } \\
\cline { 2 - 3 } & $\mathrm{KN}$ & $\mathrm{N}$ \\
\hline Load 1 & 60.84 & 60841.60 \\
\hline Load 2 & 70.25 & 70249.40 \\
\hline Load 3 & 90.16 & 90163.70 \\
\hline
\end{tabular}




\subsection{Verification Result}

\subsubsection{Experiment result in lateral load $90 \mathrm{KN}$}

Fig. 11 shows the load-displacement curve between the Finite element modeling and the Hakas experiment on the lateral force of $90 \mathrm{KN}$. From the Figure 12 can be seen that the experimental results have the plastic condition at $81 \mathrm{KN}$ load and Finite element modeling have plastic conditions at the load $82.13 \mathrm{KN}$, there is a difference of $1.4 \%$ between the experiment results and Finite element modeling.

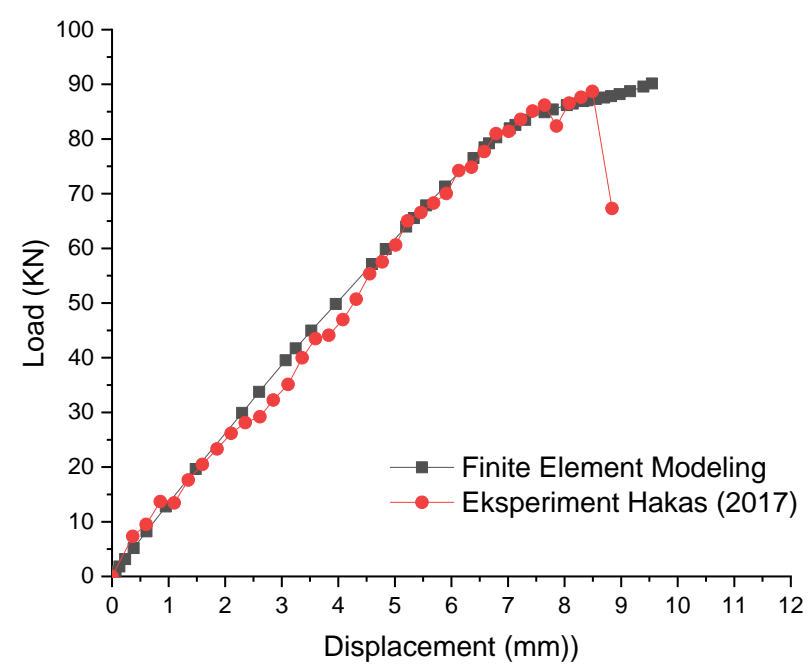

Fig 11. The load-displacement curve between the Finite element modeling and Hakas experiment on the lateral force of $90 \mathrm{KN}$ in a solid wall

\subsubsection{Natural Frequency}

Fig. 12 show natural frequency Finite element model in condition without load have $39.625 \mathrm{~Hz}$ and in fig. 13 show with load $90 \mathrm{KN}$ have natural frequency $33.12 \mathrm{~Hz}$

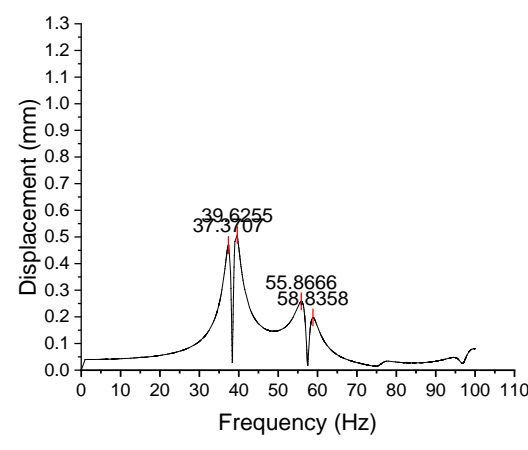

Fig. 12 Frequency-displacement Curve without load condition

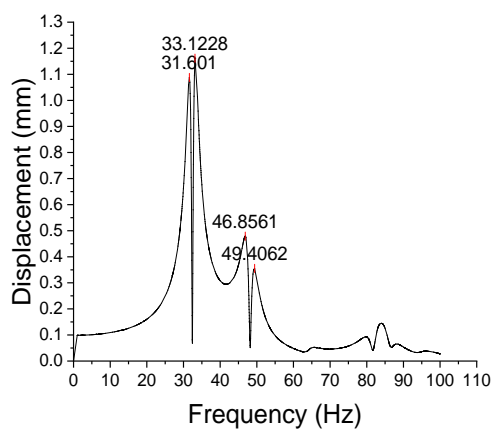

Fig. 13 Frequency-displacement Curve with load 90 $\mathrm{KN}$

Fig. 14 show natural frequency Finite element model in condition $70 \mathrm{KN}$ load have $37.72 \mathrm{~Hz}$ and in fig. 15 show with load $60 \mathrm{KN}$ have a natural frequency of $38 \mathrm{~Hz}$ 

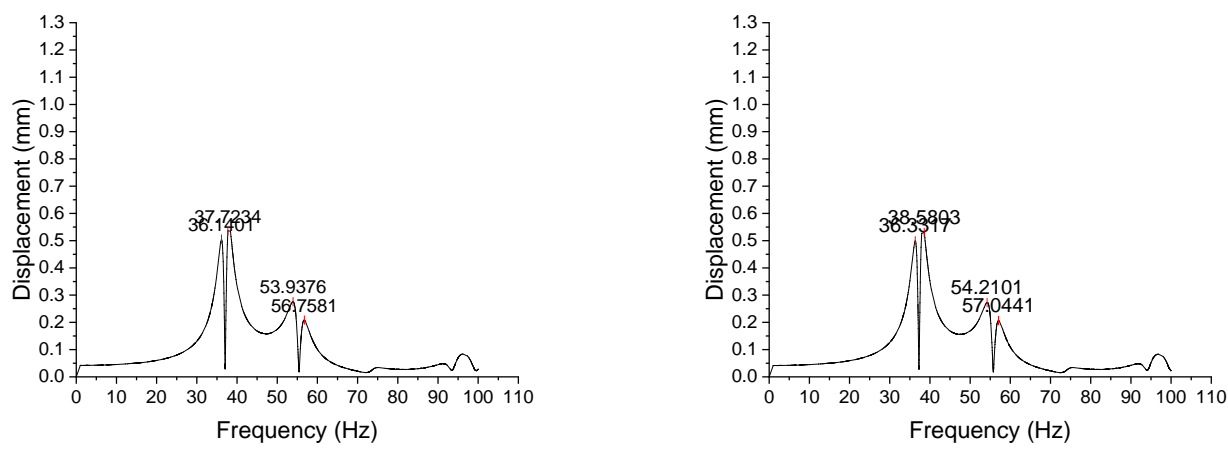

Fig. 14 Frequency-displacement Curve with load 70 KN Fig. 15 Frequency-displacement Curve with load 60 KN

Compared natural frequency between the Finite element model and experiment by Hakas [1] can be seen in Table 3:

Table 3. Compared natural frequency between finite element modeling and experiment Hakas (2017)

\begin{tabular}{llccc}
\hline \multirow{2}{*}{ No } & Condition & \multicolumn{3}{c}{ Result } \\
\cline { 3 - 4 } & & Finite Element Modeling & Eksperiment Hakas (2017) & Difference \\
& & $\mathrm{Hz}$ & $\mathrm{Hz}$ & \\
\hline 1 & Without Load & 39.62 & 40.58 & 2.37 \\
\hline 2 & Load 60.84 KN & 38.58 & 39.74 & 2.92 \\
\hline 3 & Load 70.25 KN & 37.72 & 38.68 & 2.48 \\
\hline 4 & Load 90.16 KN & 33.12 & 32.43 & 2.13 \\
\hline
\end{tabular}

The difference in result between the simulation model of finite element and experiment Hakas (2017) fluctuated between $1.4 \%$ and $2.92 \%$. The results of verification of the model allow to state that the model of finite element correctly reflects the behavior of masonry under lateral force.

\section{Variation of Finite Element Model}

Model of the finite element will be a variation with the openings in the different area. The openings are placed in the middle of the masonry wall. Variation of area opening wall can be seen in table 4 and fig. 16

Table 4. Variation of area opening wall

\begin{tabular}{|c|c|c|}
\hline No & Type of Masonry & $\%$ of area opening wall \\
\hline 1 & Solid Wall & 0 \\
\hline \multirow{3}{*}{2} & \multirow{3}{*}{1 Opening wall } & 10 \\
\hline & & 30 \\
\hline & & 50 \\
\hline \multirow{2}{*}{3} & \multirow{2}{*}{2 Opening Wall } & 10 \\
\hline & & 30 \\
\hline \multirow{2}{*}{4} & \multirow{2}{*}{3 Opening Wall } & 10 \\
\hline & & 30 \\
\hline
\end{tabular}




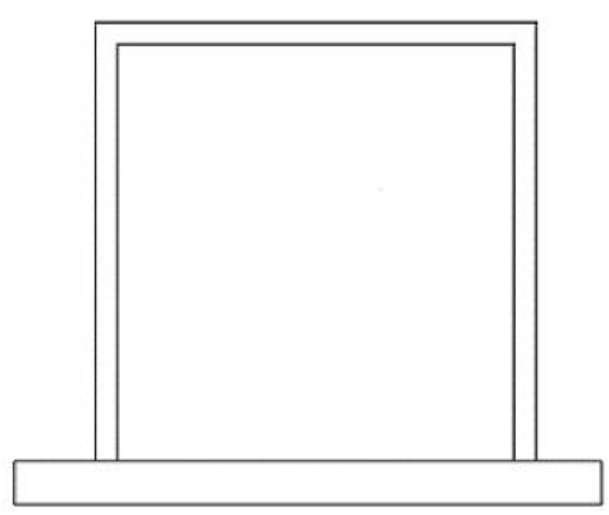

Type solid Wall

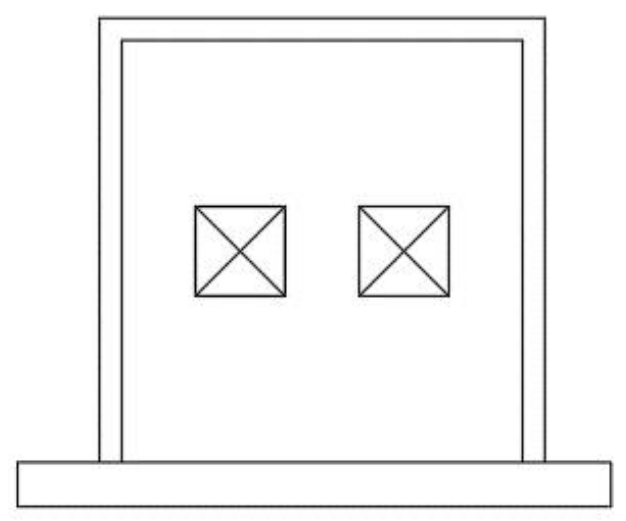

Type 2 Opening Wall

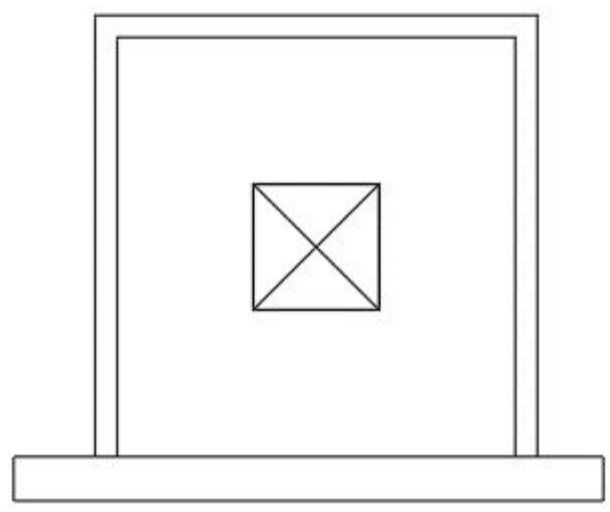

Type 1 Opening Wall

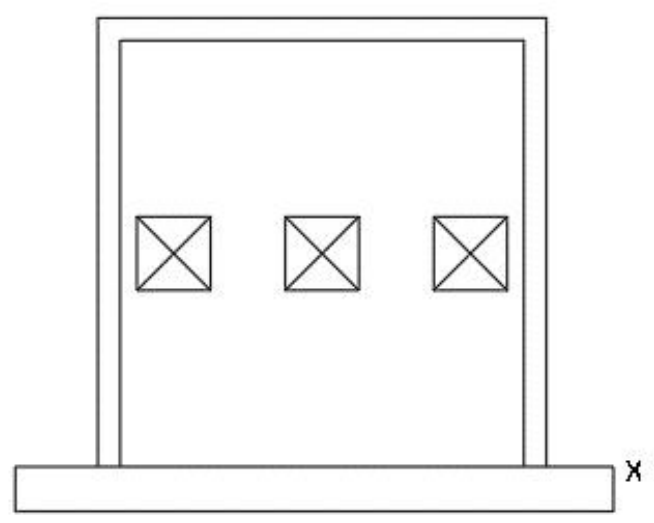

Type 3 Opening Wall

Fig 16. Variation of opening wall

\section{Result}

\subsection{Effects of opening wall}

Fig. 17 show the load-displacement curve in 1 opening wall with a different area. From the fig. 17 we can see that increase $\%$ of area opening wall make stiffness and strength of masonry wall decrease. Fig. 18 show lateral resistance of masonry wall under lateral force. From fig 18, we can see $10 \%$ area of the opening wall will decrease $50.34 \%$ lateral resistance of masonry wall and decrease $76.44 \%$ in $30 \%$ area opening and $85.68 \%$ in $50 \%$ area opening. 


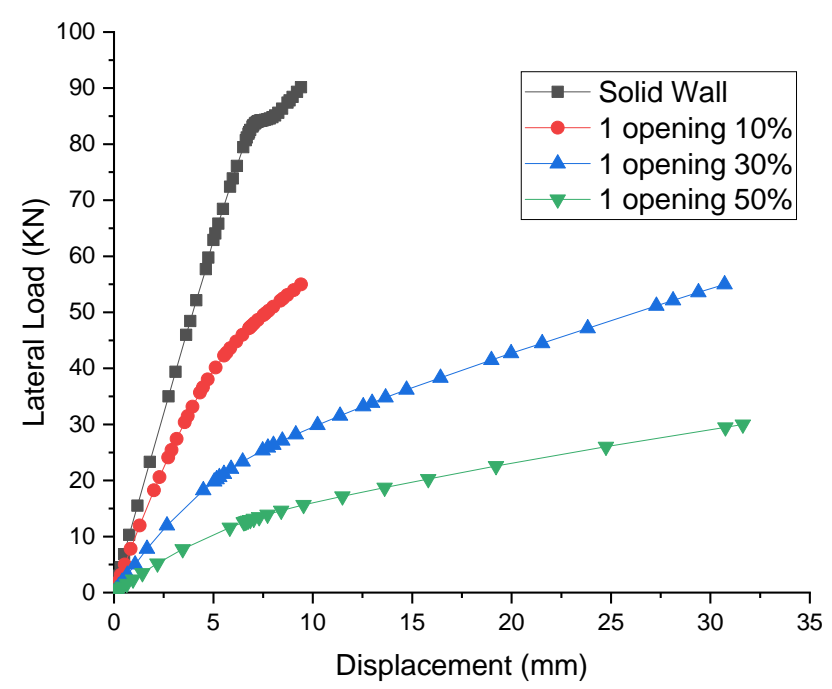

Fig. 17 The load-displacement curve in 1 opening wall

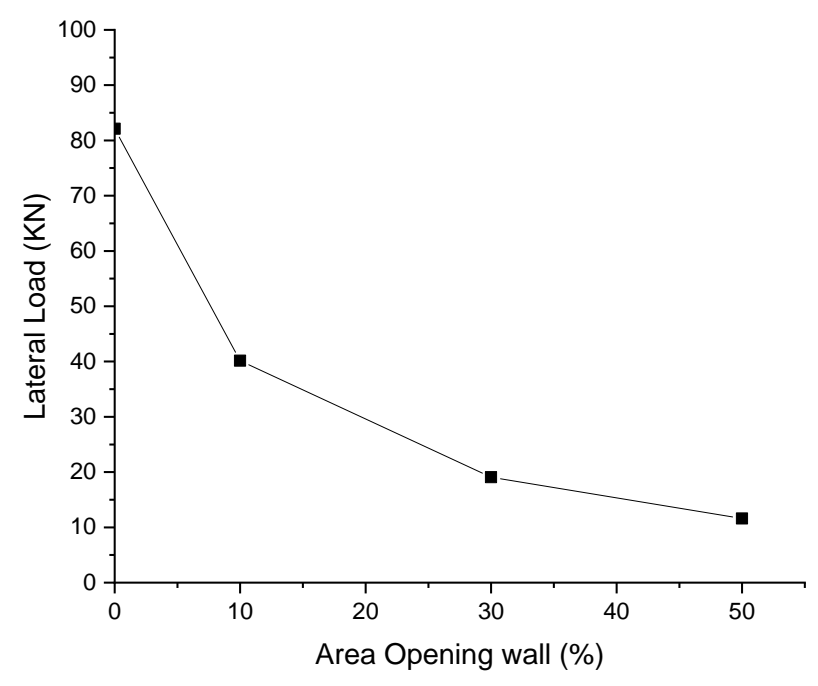

Fig. 18. Lateral resistance of masonry wall with 1 opening

Fig. 19 show the load-displacement curve in 2 opening wall with a different area. In masonry with 2 opening increase \% area in the wall make Stiffness and strength of masonry wall will decrease. From the fig. 20 we can see 2 opening wall with $10 \%$ of the area will decrease $57.11 \%$ lateral resistance of masonry and $30 \%$ of the area will decrease $85.8 \%$ lateral resistance of masonry wall 


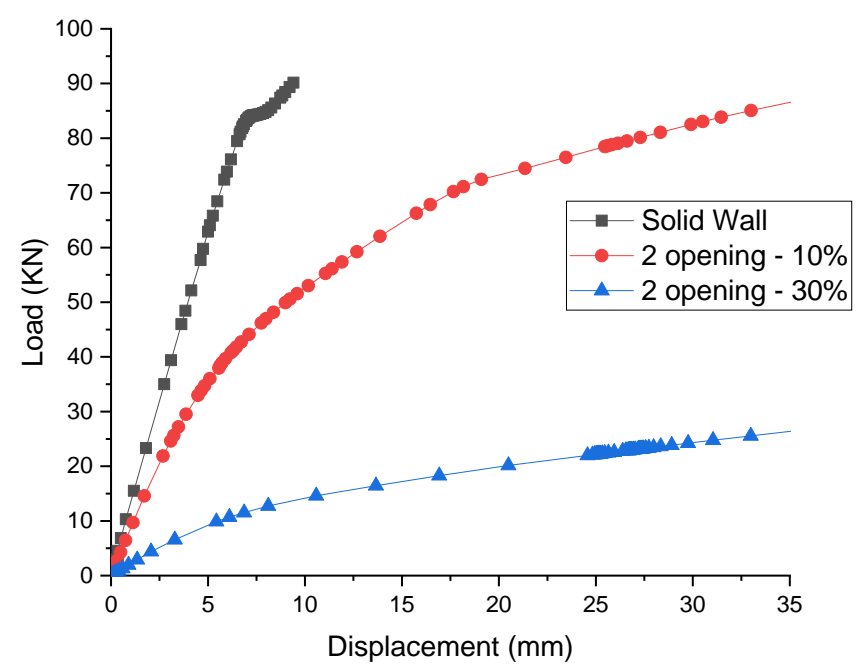

Fig. 19 The load-displacement curve in 2 opening wall

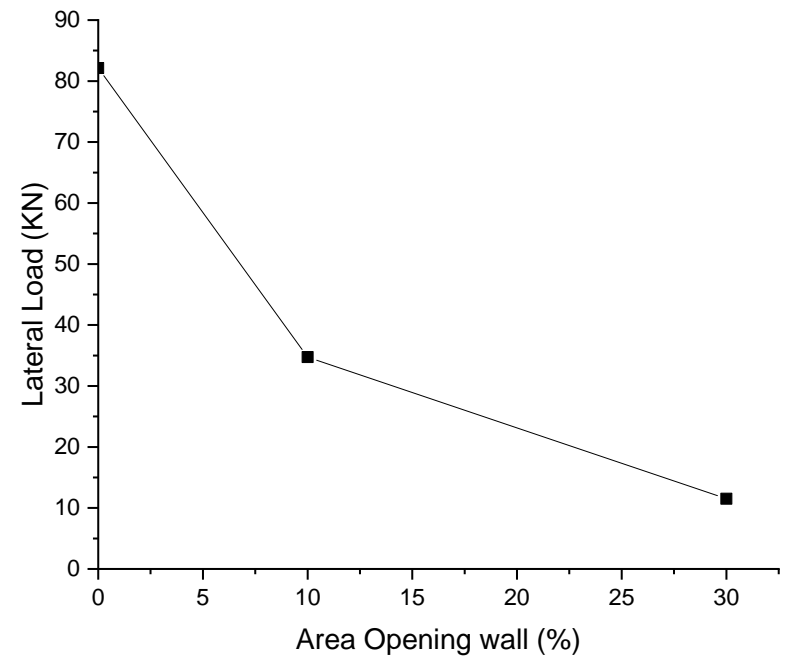

Fig. 20. Lateral resistance of masonry wall with 2 opening

Fig. 21 show the load-displacement curve in 3 opening wall with a different area. From the fig. 22 we can see 3 opening wall with $10 \%$ of the area will decrease by $64 \%$ lateral resistance of masonry and $30 \%$ of the area will decrease by $87 \%$ lateral resistance of masonry wall 


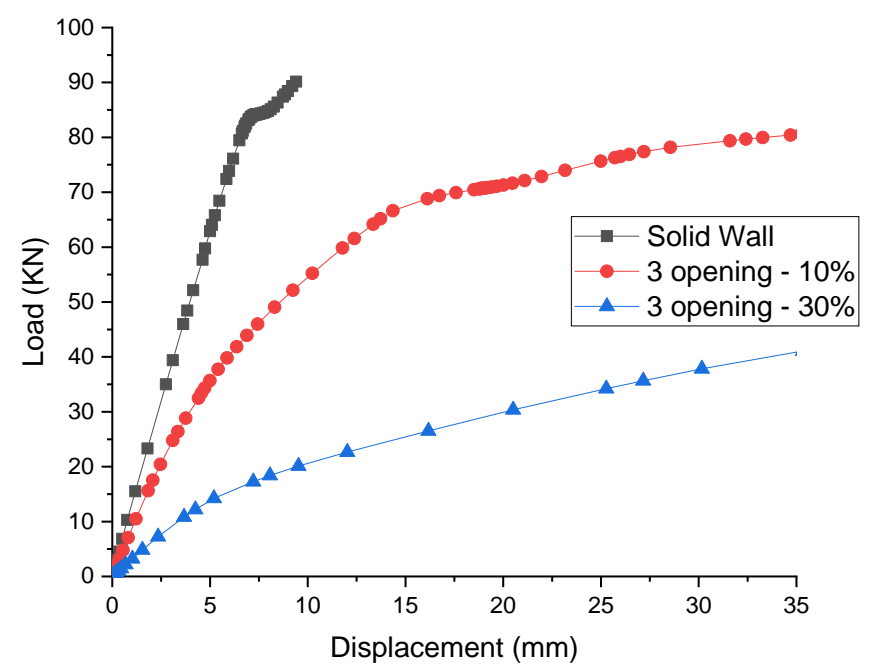

Fig. 21 The load-displacement curve in 3 opening wall

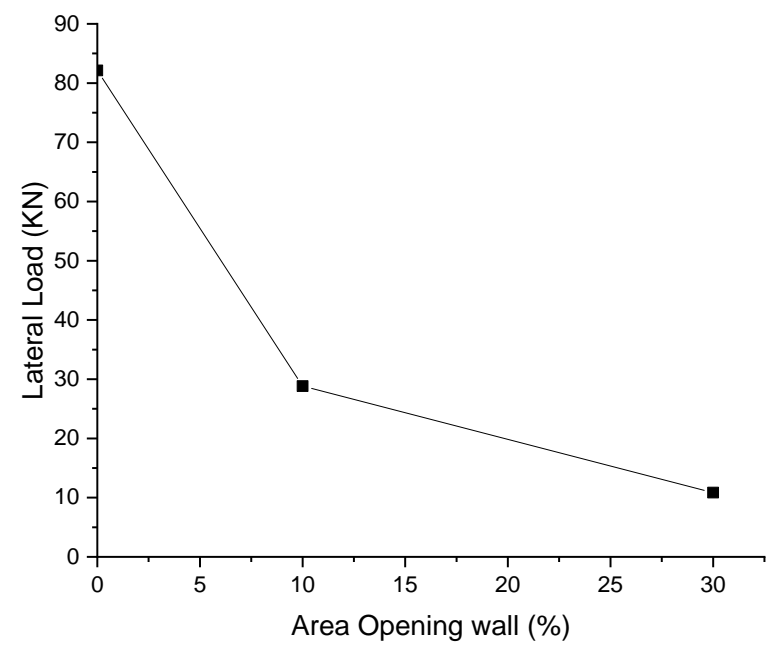

Fig. 22. Lateral resistance of masonry wall with 3 opening

Fig. 23 show the Load-Displacement curve in 10\% area opening wall and fig. 24 show LoadDisplacement curve in $30 \%$ area opening wall. We can see masonry with $10 \%$ of the area opening wall almost have same stiffness even though it has different opening types but in $30 \%$ of the opening wall, Stiffness of masonry wall will decrease following the increase of type opening wall 


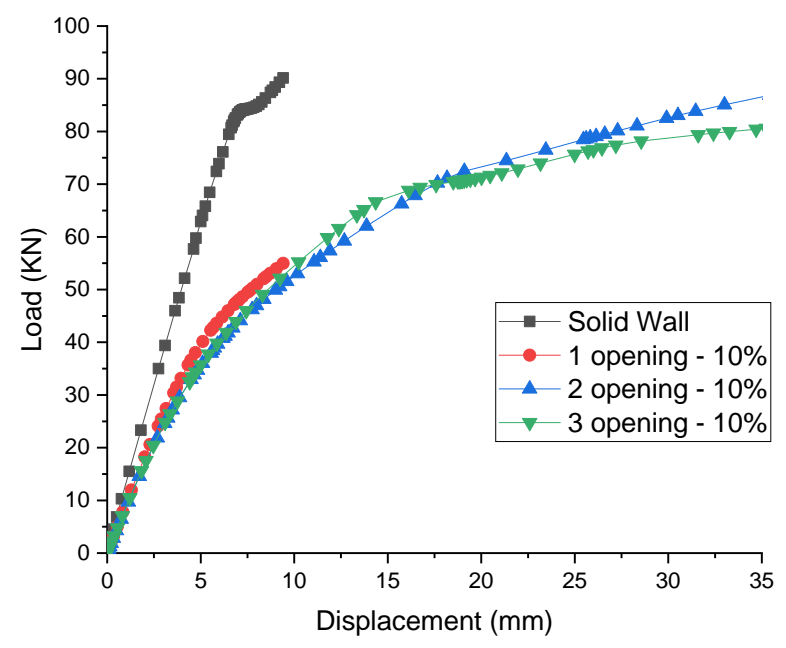

Fig. 23 The load-displacement curve in $10 \%$ area opening wall

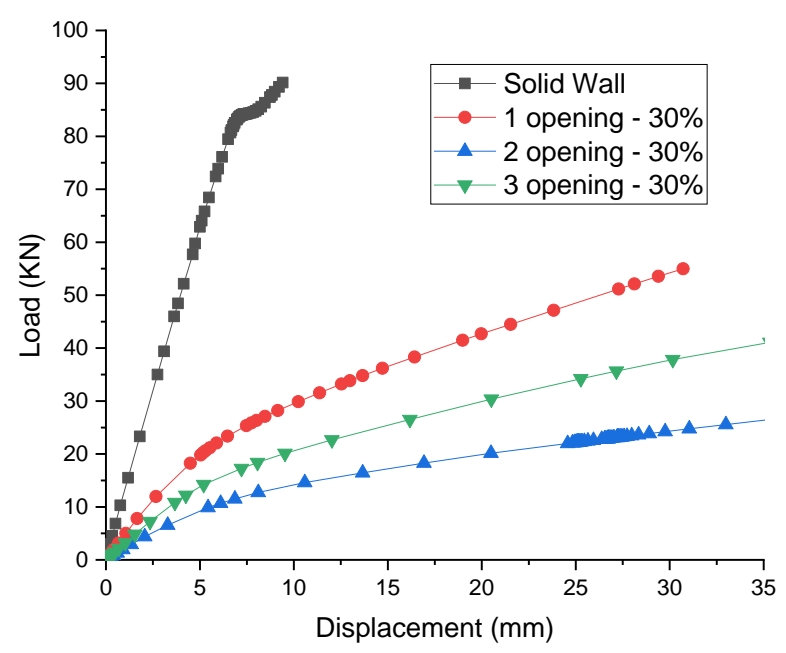

Fig. 24 The load-displacement curve in $30 \%$ area opening wall

\subsection{Finite element damage patterns}

Fig 25 - fig 30 show damage patterns in a masonry wall in the difference area. From the figure, we can see damage will begin in column concrete in the bottom of the corner and continue to the masonry wall at the corner of the opening wall. Increase area opening of the wall makes damage of masonry wall bigger. 


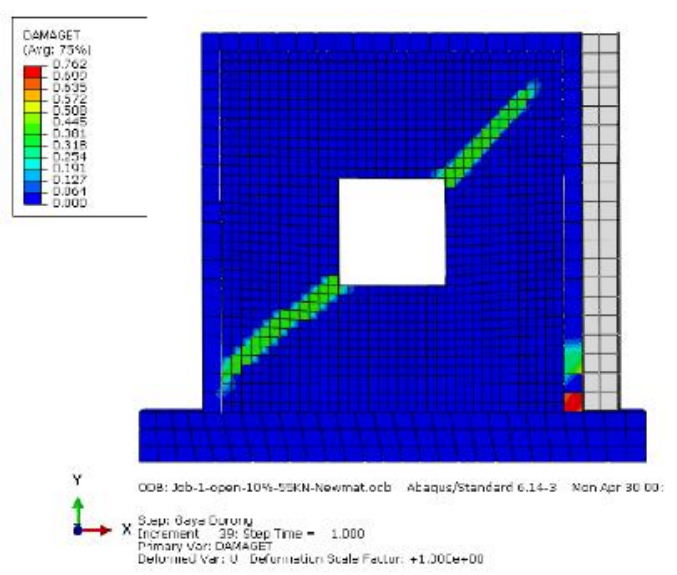

Fig. 25 Damage patterns in 10\% of the area opening wall- type 1 opening wall

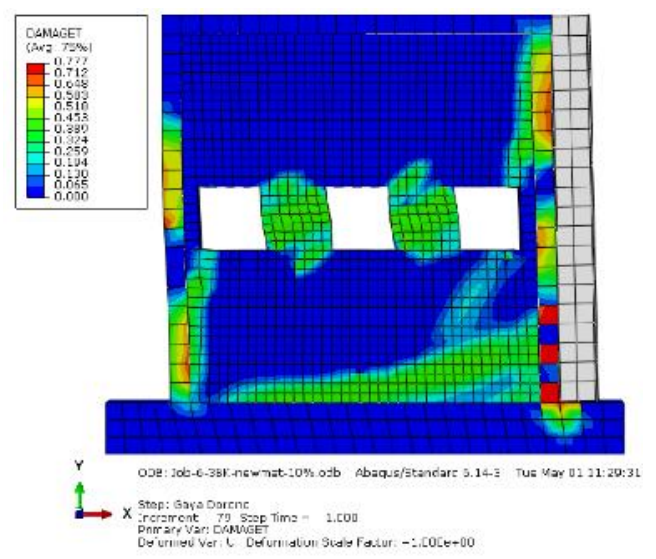

Fig. 27 Damage patterns in 10\% of the area opening wall - type 3 opening wall

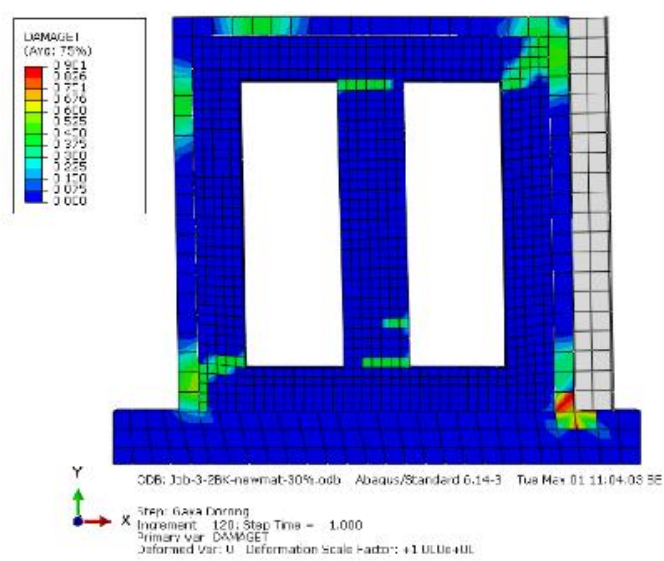

Fig. 29 Damage patterns in 30\% of area opening wall - type 2 opening wall

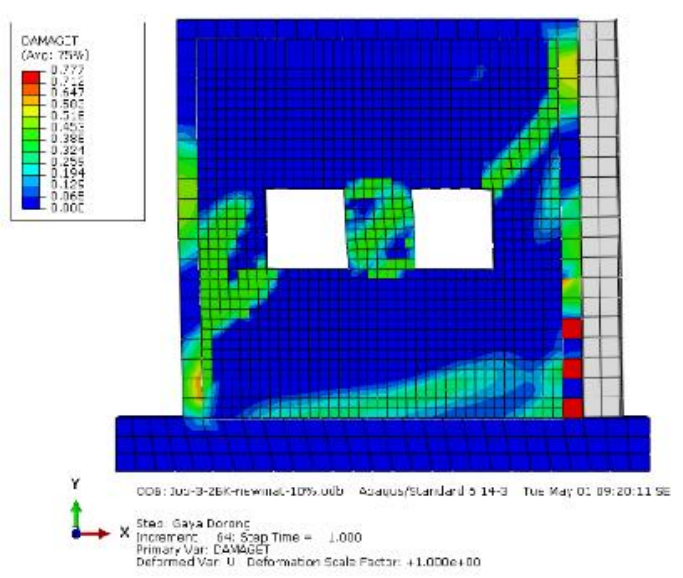

Fig. 26 Damage patterns in $10 \%$ of the area opening wall - type 2 opening wall

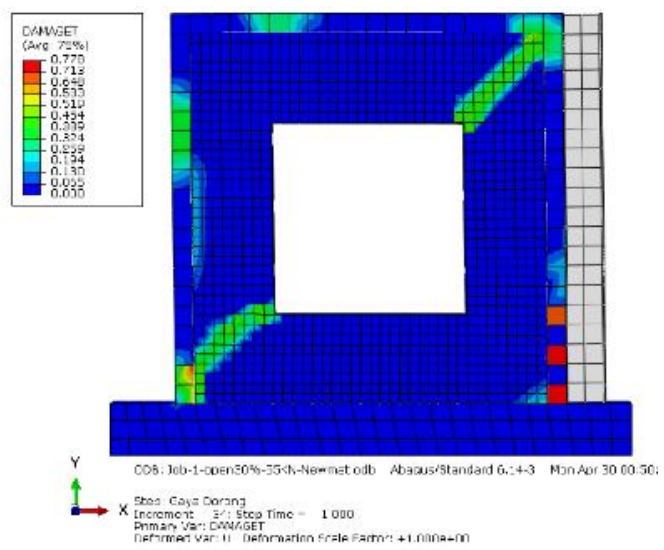

Fig. 28 Damage patterns in 30\% of area opening wall - type 1 opening wall

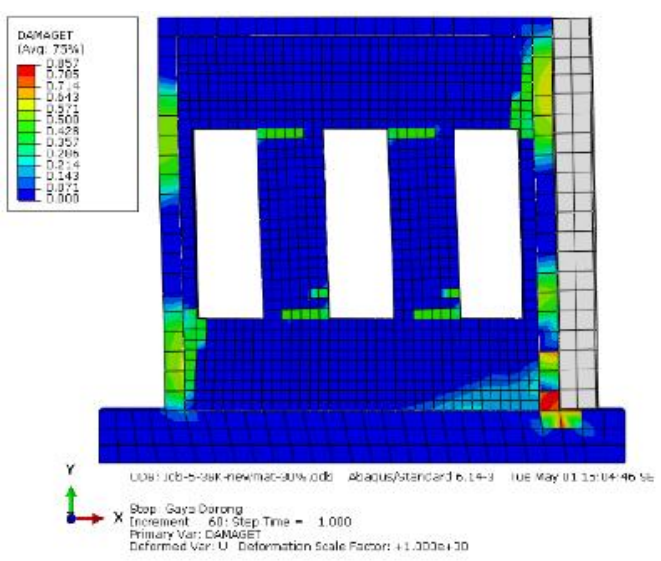

Fig. 30 Damage patterns in 30\% of the area opening wall - type 3 opening wall 


\section{Conclusions}

Based on the results of this research, using integrated modeling Finite Element Models of an opening masonry wall with the ABAQUS software. The obtained results are discussed:

1. The Finite Element model using the ABAQUS Software can represent the loaddisplacement curve of Masonry walls under lateral forces.

2. Increase area opening wall make stiffness and strength of the masonry wall decrease.

3. A masonry wall with a type of 1 opening, In lateral resistance, will decrease were $50.34 \%$, $76.44 \%$, and $85.68 \%$ respectively for each area of the opening wall

4. A masonry wall with a type of 2 opening, In lateral resistance, will decrease were $57.11 \%$, and $85.8 \%$ respectively for each area of the opening wall

5. A masonry wall with a type of 3 opening, In lateral resistance, will decrease were $64 \%$, and $87 \%$ respectively for each area of the opening wall

6. Masonry with $10 \%$ of area opening wall have the same stiffness even though it has different opening types

7. Masonry with $30 \%$ of area opening wall, Stiffness of masonry wall will decrease following increase of type opening wall

\section{References}

[1] Hakas, P, Berkat, C, Z.Priyosulistyo, H., Prediction of allowable Lateral Ground acceleration (in-Plane direction) of confined masonry wall using ambient vibration (microtremor) analysis, Procedia Engineering 171 ( 2017 )

[2] Iman, S, 2008, Some Practical Aspect in the Post Yogyakarta Earthquake Reconstruction of Brick Masonry Houses, The Yogyakarta Earthquake Of May 27, 2006.

[3] Archana, D, Pradeep, K, R., Effect Of Openings and Aspect ratio on overall performance of RC framed brick infilled Building, 16th World Conference on Earthquake, January 2017.

[4] Bashar, S.M., Badorul, H, Choong, K, K, The Effects of Opening on the Structural Behavior of Masonry Wall Subjected to Compressive Loading - Strain Variation. The Open Civil Engineering Journal, 2009

[5] Putra, A, N., Pengaruh letak bukaan terhadap kinerja Dinding Bata Terkekang Dengan Beban Siklik lateral, Naskah Publikasi, 2016

[6] Stavridis A, Shing PB. Calibration of a numerical model for masonry infilled RC frames. In: The 14th world conference on earthquake engineering, Beijing 2008.

[7] Mohyeddin, A, et al, 2013, FE modeling of RC frames with masonry infill panels under inplane and out-of-plane loading, SciVerse ScienceDirect

[8] Al-Chaar G. Non-ductile behavior of reinforced concrete frames with masonry infill panels subjected to in-plane loading [Ph.D.]. Chicago: the University of Illinois at Chicago; 1998

[9] D'Ayala D, Worth J, Riddle O. Realistic shear capacity assessment of infill frames: comparison of two numerical procedures. Eng Struct 2009;31: 1745-61

[10] Stavridis A, Shing PB. Finite-element modeling of the nonlinear behavior of masonryinfilled RC frames. J Struct Eng 2010;136:285-96

[11] Chen, F., a Zhang, w., Damage Simulation of Masonry Wall Based on The Finite Element Software Abaqus, Advanced Materials Research Vols 1008-1009 (2014)

[12] Meillyta, Finite Element Modelling of Unreinforced Masonry (URM) Wall with Openings: Studies in Australia, The Proceedings of 2nd Annual International Conference Syiah Kuala University 2012

[13] Moghadam HA, Goudarzi N. Transverse resistance of masonry infills. ACI StructJ 2010;107:461-7. 
[14] BSI, British Standards, Design of concrete structures - Part 1-1: General rules and rules for buildings, BS EN 1992-1-1:2004

[15] Wang, T, and Hsu, Thomas, Non-Linear Finite Element analysis of concrete structure using a new constitutive model, Computers and structure 79 (2001) 2781-2791

[16] T.Paulay, M.J.N. Priestley, Seismic Design of Reinforced Concrete and Masonry Buildings, 1edition, Wiley-Interscience, NewYork,1992.

[17] Kaushik, Hemant et al, a Uniaxial compressive stress-strain model for clay brick masonry, Current Science, Vol 92, No 4, 25 February 2007

[18] Chen, et al, Moment/thrust interaction diagrams for reinforced masonry sections, Construction and Building Materials 22 (2008) 763-770 